\title{
Ergonomik Personel Görev Çizelgeleme Problemi: Çok Amaçlı Bir Kısıt Programlama Modeli ve Vaka Çalışması
}

\author{
Ergonomic Personnel Task Scheduling Problem: A Multi-objective Constraint \\ Programming Model and A Case Study
}

\author{
Mehmet Pınarbaşı1 iD \\ ${ }^{1}$ OSTIM Teknik Üniversitesi, 06374 Yenimahalle Ankara, TÜRKIYE
}

Başvuru/Received: 19/07/2021

Kabul / Accepted: 18/09/2021

Çevrimiçi Basım / Published Online: 31/01/2022

Son Versiyon/Final Version: 31/01/2022

\begin{abstract}
Öz
Personel görev çizelgeleme problemi (PGÇP) firma amaçlarını ve teknolojik kısıtlarını dikkate alarak firma personellerine görev atanması problemidir. Ergonomik faktörler görevin yerine getirilmesi esnasında personeller üzerindeki yükün değerlendirilmesi için dikkate alınırlar. Personel verimliliğini artırmak isteyen işletmeler ergonomik risklerin azaltılması yönünde kararlar almaya zorlanmaktadır. Bunun yanı sıra personel giderleri üretim maliyetleri içerisinde önemli bir yer tutmaktadır. Gerek işçilik maliyetlerini düşürmek gerekse personel üretkenliğini artırmak için ergonomik risk faktörleri göz önünde bulundurularak PGÇP çözülmek zorundadır. Bu çalışmada ergonomik personel görev çizelgeleme problemi (EPGÇP) için bir kısıt programlama (KP) modeli önerilmiştir. Personel ergonomik risk skorlarının belirlenmesinde REBA metodu kullanılmıştır. Modelin amaç fonksiyonu, amaç programlama tabanlı olarak belirlenen ergonomik risk skorlarından sapmaların en küçüklenmesidir. Önerilen modelin performansı orta gerilim sigorta üretimi yapan bir firmadan alınan gerçek veriler ile değerlendirilmiştir. Sayısal test sonuçları literatürde PGÇP için çözüm önerisi sunan çalışmalar ile karşılaştırılmıştır. Sonuçlar önerilen KP modelinin problemin çözümünde etkin ve verimli olduğunu göstermiştir.
\end{abstract}

\section{Anahtar Kelimeler}

"Personel görev çizelgeleme problemi, Klsit programlama, Ergonomi, REBA, Orta gerilim sigorta"

\begin{abstract}
Personnel task scheduling problem (PTSP) is the problem of assigning tasks to personnel, taking into account firm objectives and technological constraints. Ergonomic factors are taken into account to assess the ergonomic risks on personnel while performing the task. Firms that want to increase personnel productivity are forced to make decisions to reduce ergonomic risks. In addition, personnel costs have an important place in production costs. To reduce labor costs and increase personnel productivity, PTSP has to solve by considering ergonomic risk factors. In this study, a constraint programming $(\mathrm{CP}) \mathrm{model}$ is proposed for the ergonomic personnel task scheduling problem (EPTSP). REBA method is used to determine personnel ergonomic risk scores. The objective function of the model is to minimize the deviations from the ergonomic risk scores determined based on goal programming. The performance of the proposed model has been evaluated with real data obtained from a company that produces medium voltage fuses. Numerical results were compared with the results of studies in the literature that proposed a solution for PTSP. The results showed that the proposed CP model is effective and efficient in solving the problem.
\end{abstract}

Key Words

"Personnel task scheduling problem, Constraint Programming, Ergonomic,, REBA, Medium voltage fuses", 


\section{Giris}

Personel bir işletmede yapılması gereken görevleri yerine getirmek ile mükellef olan iş gücünü temsil etmektedir. İş gücü ve üretim sürecinden kaynaklanan maliyetlerin toplamı nihai ürünün maliyetini oluşturmaktadır. Günümüz rekabetçi ortamında düşük maliyet ile üretim süreçlerini kontrol edebilmek işletmelerin pazar payında ciddi artışlara neden olmaktadır. Bu sebeple maliyetin ciddi bir bölümünü oluşturan iş gücünün etkin planlanması işletmelere mali açıdan büyük avantajlar getirecektir (Alakaş vd., 2020).

Yaşanan salgın süreci firmaları personel kapasitesi olarak kısıtlamalara gitmek zorunda bırakmıştır. Bu tür zorunlu kısıtlamalar doğal olarak işletme kapasitesinin düşmesine neden olmuştur. Her ne kadar salgın süreci kısıtlamalar ve yasaklar getirse de üretim süreçleri insan ihtiyaçlarının giderilebilmesi adına çalışmak zorunda kalmıştır. Oluşan talebi salgın-işgücü kısıtlamaları altında karşılamak firmaları zorlayıcı bir problem haline dönüşmüştür. İşletme kapasitesini en yüksek seviyede kullanarak talebi karşılamak adına kısıtlı işgücünü planlama zorunluluğu doğmuştur. Personel görev çizelgeleme problemi (PGÇP) bir veya birkaç amacı eniyilemek için işgücü kısıtlamaları, insani kısıtlamalar, mesai zamanı kısıdı, yetenek kısıtları gibi kısıtlamalar altında firmada gerçekleşecek görevlere personel atayan işgücü planlaması problemidir (Pınarbaşı ve Alakaş, 2020).

Ergonomi insanların fiziksel ve psikolojik karakteristiklerini dikkate alarak insan-makine sistemlerinin geliştirilmesi için çalışılan bir bilim dalıdır. Salgın süreci göstermiştir ki hastalığa yakalanan bireyler fiziksel ve psikolojik olarak ne kadar güçlü iseler hastalığı o derecede hızlı atlatmaktalar ve daha az etkilenmektedirler. İnsanların çalıştığı ortamda maruz kaldığı ergonomik yüklerin azaltılması insanların direncini de artıracaktır. Bu sebeple işgücünün maruz kalacağı ergonomik risk faktörlerinin ölçülmesi gerekmektedir. Ergonomik risk faktörleri REBA gibi çeşitli yöntemler vasıtasıyla gözlem ve ölçümlere dayalı olarak tespit edilir. Yüksek risk faktörüne sahip görevlerin dengeli dağılımı, personeli kas iskelet sistemi hastalıklarına karşı korumak, personelin iş stresini azaltmak, iş memnuniyetini ve moralini artırmak gibi avantajları beraberinde getirecektir. Hem salgın sürecinde personel sağlığını korumak hem de personeli ergonomi kaynaklı risklerden arındırmak adına personel görev çizelgeleme probleminin ergonomik riskleri de göz önünde bulundurarak ele alınması gerekmektedir. Bu problem ergonomik personel görev çizelgeleme problemi (EPGÇP) olarak adlandırılır.

Personel çizelgeleme problemi gibi kombinatoryal problemler genellikle bir amaç fonksiyonunu eniyilemek amaciyla modellenirler. Ancak bazı durumlarda karar verici birden fazla çelişen amacı aynı anda karşılamak zorunda kalabilir. Birden fazla amacı dikkate alan kombinatoryal problemlere çok amaçlı karar problemleri denilmektedir. Bu tür problemlerin çözümü için literatürde tek amaçlı problemlerin çözüm yöntemlerinden farklı yöntemler geliştirilmiştir. Bu yöntemler çok kriterli karar verme yöntemleri, amaç programlama ve çok amaçlı sezgiseller olarak verilebilir. Amaç programlama çok amaçlı problemlerin çözümünde kullanılan en güçlü yöntemlerden biridir (Charnes and Cooper, 1977). Bu yöntem en iyilenmesi gereken her bir amaç için bir sapma değeri belirleyerek, bu sapma değerlerinin en iyileşmesini ve doğrudan tüm amaçların belirli seviyelerde sağlanmasına olanak veren bir yöntemdir. Sapma değerlerine ulaşılma seviyesi yöntemin ilgili amacı ne derecede sağladığı ile ilgilidir.

Kombinatoryal problemlerin çözümü için geliştirilen yöntemleri en genel anlamı ile tam/kesin ve sezgisel yöntemler olarak sınıflandırmak mümkündür. Tam yöntemler tam sayılı programlama, dal sınır algoritması gibi yöntemler iken sezgisel yöntemlere tabu arama, genetik algoritmalar, tavlama benzetimi gibi yöntemler örnek olarak verilebilir. Sezgisel yöntemler kısa zamanda problem için bir çözüm üretirken kesin yöntemler problem için optimum çözümü üreten yöntemlerdir. Kesin yöntemler sezgiseller kadar kısa sürede çözüm üretemeseler de çözüm arama stratejilerinde yapılacak iyileştirmeler, etkin model kurma teknikleri, gelişmiş ön işlem mekanizmaları gibi yöntemler ile kısa sürede çözüme ulaşma imkanı vermektedirler. Kısıt programlama (KP) son zamanlarda atama problemleri, çizelgeleme ve montaj hattı dengeleme gibi birçok üretim probleminin çözümünde etkin olarak kullanılan bir kesin çözüm yöntemidir (Pınarbaşı, 2021). KP problemin amaç ve kısıtlarında meydana gelecek değişiklikleri kolayca modellemek adına bilgisayar programlamanın etkili yönlerini kullanmaktadır. Bunun yanı sıra matematiksel programlamanın çözüm arama etkinliğini bu modelleme avantajı ile birleştirerek etkin ve hızlı çözüm bulmaya imkan vermektedir. Probleme özgü çözüm arama stratejisi geliştirebilme imkanı da KP'nin bir diğer avantajıdır. Bu sebeplerle çalışmada EPGÇP çözümü için KP modeli üzerinde durulacaktır.

$\mathrm{Bu}$ çalışmada personel çizelgeleme problemi görevlerin ergonomik risk faktörlerini de göz önünde bulundurarak ele alınmıştır. Problemin çözümü için bir çok amaçlı KP modeli önerilmiştir. Modelin amaçlarını her bir görev için hesaplanan üç ayrı REBA puanının en iyilenmesi oluşturmaktadır. Bu üç farklı amaç için oluşturulan sapma değişkenleri KP modeline entegre edilerek yeni bir amaç programlama temelli KP model önerisi yapılmıştır. Modelin etkinliği gerçek veriler ile oluşturulan bir vaka analizi ile test edilmiştir ve literatür çözümleri ile kıyaslanmıştır. Sonuçlar geliştirilen modelin problemin çözümü için etkin ve umut vadedici olduğunu göstermiştir.

Çalışmanın içerik organizasyonu şu şekilde planlanmıştır. Giriş bölümünden sonra Bölüm 2'de literatür araştırması verilmiştir. Bölüm 3 'te personel görevlerinin ergonomik açıdan değerlendirilmesi için kullanılan REBA yönteminden bahsedilmiştir. Problem tanımı ve EPGÇP'nin çözümü için önerilen KP modeli Bölüm 4'te sunulmuştur. Bölüm 5 önerilen modelin performansının test edildiği vaka çalışmasının detayları ve sayısal sonuçları içermektedir. Bölüm 6 ile çalışma sonuçlandırılmıştır. 


\section{Literatür Araştırması}

PGÇP literatürü incelendiğinde benzer problemin farklı amaç veya kısıtlar ile farklı isimler adı altında ele alındığ görülmüştür. Bu çalışma EPGÇP ve çözüm yöntemleri ile ilgili olduğundan sadece EPGÇP literatürü üzerine yoğunlaşılacaktır. Geleneksel PGÇP literatürü için Özder vd. (2020) ve Adem ve Dağdeviren (2016) çalışmaları incelenebilir. EPGÇP literatürü için (Adem ve Dağdeviren, 2016) çalışması geliştirilerek yeni çalışmalar eklenmiş ve özet literatür Tablo 1'de verilmiştir.

Tablo 1, EPGÇP için geliştirilen çözüm yöntemleri açısından incelediğinde, üç temel çözüm yöntemi dikkat çekmektedir: kesin/matematiksel yöntemler, sezgisel yöntemler ve benzetim. Kesin yöntemleri, matematiksel programlama (Anzanello vd., 2014; Boenzi vd., 2015; Mossa vd., 2016), tam sayılı programlama (Carnahan vd., 2000; Malladi ve Min, 2004; Seçkiner ve Kurt, 2005; Wongwien ve Nanthavanij, 2012; Wongwien ve Nanthavanij, 2013; Otto ve Scholl, 2013), karışı tam sayılı programlama (Rattanamanee ve Nanthavanij, 2013) ve amaç programlama (Bedir vd., 2017; Kaçmaz vd., 2020; Alakaş vd., 2020) olarak sınıflandırmak mümkündür. Sezgisel yöntemler probleme özgü sezgisel arama metotları (Yaoyuenyong ve Nanthavani, 2006; Wongwien ve Nanthavanij, 2012; Otto ve Scholl, 2013; Boenzi vd., 2015; Anzanello vd., 2014) ve genetik algoritma (Carnahan vd., 2000; Cuesta vd., 2012) olarak verilebilir. Bu çözüm yöntemlerine ek olarak problem parametrelerinin belirlenmesi veya amaç programlamada amaç ağırlıklarının tespiti amacıyla AHP yöntemine literatürde sıklıkla başvurulduğu görülmektedir.

EPGÇP’nin literatür çalışmalarının derlenmesinde kullanılabilir bir kriter de çalışmanın dikkate aldığı ergonomik ölçütlerdir. Literatür çalışmalarında çok farklı ölçütler dikkate alınmıştır: OCRA indeks (Cuesta vd., 2012; Boenzi vd., 2015; Mossa vd., 2016), REBA skor (Kaçmaz vd., 2020; Alakaş vd., 2020), yorgunluk (Wang ve Cheng, 2014), gürültü (Yaoyuenyong ve Nanthavani, 2006; Wongwien ve Nanthavanij, 2012), radyasyon (Seçkiner ve Kurt, 2005), uyku, (Kostreva vd., 2002) görev karmaşıklığı (Anzanello vd., 2014). REBA metodu son yıllarda ergonomik riskleri hesaplamada kullandığı matematiksel altyapı nedeniyle ölçülebilir ergonomik skorlar açısından en popüler metot haline gelmiştir (Alakaş vd., 2020).

Tablo 1'de özetlenen literatür çalışmaları uygulama alanı açısından değerlendirildiğinde hizmet ve üretim sistemi olarak iki farklı sektörel uygulamaya rastlanmaktadır. Literatürdeki çalışmaların yarısı herhangi bir uygulama alanı içermeyen (sayısal analizler yazarlardan tarafından üretilmiş veriler ile yapılmışır) çalışmalardan oluşurken diğer yarısının daha çok ayakkabı üretimi, otomobil üretimi, sigorta ve cam üretimi gibi üretim sektörüne dönük uygulamalar yaptığı görülmektedir. Üretim sektöründe yapılan uygulamanın çok olmasının nedeni personel ergonomik riskinin hizmet sektörüne göre üretim sektöründe daha yüksek olduğu ile açiklanabilir.

Tablo 1. EPGÇP Literatür çalışmaları (Adem ve Dağdeviren, 2016)

\begin{tabular}{|c|c|c|c|}
\hline Çalışma & Ergonomik ölçüt & $\begin{array}{l}\text { Çözüm } \\
\text { yöntemi }\end{array}$ & Uygulama alanı \\
\hline Carnahan vd. (2000) & $\begin{array}{l}\text { Taşınan nesne ağırlığ } 1 \text {, taşıma mesafesi, tekrarlama } \\
\text { sıklığ } 1\end{array}$ & TP, GA & - \\
\hline Malladi ve Min (2004) & Finansal ve ergonomik faktörler & TP, AHP & - \\
\hline Seçkiner ve Kurt (2005) & Radyasyon miktarı & $\mathrm{TP}$ & Hastane \\
\hline $\begin{array}{l}\text { Yaoyuenyong ve } \\
\text { Nanthavani (2006) }\end{array}$ & Gürültü değeri & TP, SA & - \\
\hline Kostreva vd. (2002) & Uyku düzeni & $\mathrm{B}$ & - \\
\hline $\begin{array}{l}\text { Wongwien ve } \\
\text { Nanthavanij (2012) }\end{array}$ & Gürültü sınır değerleri & TP, SA & - \\
\hline $\begin{array}{l}\text { Wongwien ve } \\
\text { Nanthavanij (2013) }\end{array}$ & Rassal risk değeri üretimi & $\mathrm{TP}$ & - \\
\hline Cuesta vd. (2012) & OCRA indeks & ECRot, GA & - \\
\hline Otto ve Scholl (2013) & Ergonomik puan & $\mathrm{TP}, \mathrm{SA}$ & Otomobil üretimi \\
\hline $\begin{array}{l}\text { Rattanamanee ve } \\
\text { Nanthavanij (2013) }\end{array}$ & Ergonomik tehlikeye maruz kalma riski & KTP & - \\
\hline Boenzi vd. (2015) & OCRA indeks & $\mathrm{MP}, \mathrm{SA}$ & - \\
\hline Wang ve Cheng (2014) & Yorgunluk indeksi & $\mathrm{B}$ & Hava Trafik Kontrolü \\
\hline Anzanello vd. (2014) & Görev karmaşıklığının dengeli dağı̆ıımı & $\mathrm{MP}, \mathrm{SA}$ & Ayakkabı üretimi \\
\hline Mossa vd. (2016) & OCRA indeks & MP & Otomobil üretimi \\
\hline Bedir vd. (2017) & Ergonomik risk faktörü & $\mathrm{AP}, \mathrm{AHP}$ & Giyim mağazası \\
\hline Kaçmaz vd. (2020) & REBA Skor & AP & Cam sanayi \\
\hline Alakaş vd. (2020) & REBA Skor & $\mathrm{AP}$ & Sigorta üretimi \\
\hline
\end{tabular}

KTP: Karışık Tam Sayılı Programlama, GA: Genetik Algoritma, TP: Tam Sayılı programlama, MP: Matematiksel Programlama, KP: Kısıt Programlama, SA: Sezgisel Arama, AP: Amaç Programlama, B: Benzetim, AHP: Analitik Hiyerarşi Süreci, ECRot: Ergonomic and Competent Rotation 
Bu çalışma EPGÇP için yeni bir kesin çözüm yöntemi olan KP modelinin kurulması ve problemin çözülmesine odaklanmıştır. KP'nin çizelgeleme problemlerinin çözümü için kullanıldığı literatür çalışmalarından bu bölümde bahsedilecektir. Rodriguez (2007) gerçek zamanlı tren çizelgeleme problemi için bir KP modeli önermiş̧ir. Yazar Paris’te yerleşik tren kavşaklarından geçen trenlerin rota planı ve çizelgesinin oluşturulması uygulaması üzerinde durmuştur. Pour vd. (2018) KP ve karışık tamsayılı programlama temelli bir çözüm yaklaşımını bakım personeli çizelgelemesinin çözümü için önermişlerdir. Çalışmada Danimarka'da bulunan bir demiryolu ağının önleyici sinyal sisteminin bakım ekibinin çizelgelemesi vaka analizi olarak sunulmuştur. Hemşire çizelgeleme problemi için tam sayılı programlama ve KP modelleri öneren bir çalışma Trilling vs. (2006) tarafından sunulmuştur. De Silva (2001) otobüs şoförü çizelgeleme problemi için doğrusal programlama ile bütünleşik bir KP modeli önerisinde bulunmuştur. KP'nin PGÇP çözümü için kullanıldığ son yıllardaki ender çalışmalara örnek vermek gerekirse Gür vd. (2019), Eren vd. (2019) ve Özcan vd. (2020) çalışmaları verilebilir. Gür vd. (2019) ameliyathane çizelgeleme problemi için amaç programlama ve KP modelleri önermişlerdir. Bir üniversite kampüsünün güvenlik personellerinin aylık çizelgesinin oluşturulması için Eren vd. (2019) tarafindan bir KP modeli önerilmiştir. Özcan vd. (2020) KP ve amaç programlamayı entegre ederek çok amaçlı vardiya çizelgeleme problemini ele almışlardır. Bir hidroelektrik santralinde çalışan personelin vardiyalara göre personel çizelgelemesi vaka analizi olarak sunulmuştur. KP modellemesi ile PGÇP'yi çözen literatür çalışmalarının ergonomik risk faktörlerini göz önünde bulundurmadığı görülmektedir.

Literatür çalışması sonuçları değerlendirildiğinde EPGÇP'nin çözümü için yeni bir kesin çözüm yöntemi olan KP'nin hiç kullanılmadığı görülmüştür. Bunun yanı sıra literatür çalışmalarının problemi genellikle tek amaçlı ergonomik risk faktörleri dikkate alarak değerlendirdiği görülmüş ve bu çalışmada REBA skorlarını birlikte dikkate alan çok amaçlı bir modelleme üzerinde durulmuştur. Ergonomik risk faktörlerinin personel üzerinde büyük oranda etkili olduğu görülen orta gerilim sigorta üretimi sektöründe çalışan bir firmadan elde edilen gerçek veriler ile bir vaka analizi yapılarak literatür desteklenmiştir. Ayrıca bu çalışmada literatürde PGÇP çözümü için geliştirilen KP modeli çalışmalarının sonuçları bu çalışmanın sonuçları ile karşılaştırmalı olarak verilerek çalışmanın literatür katkısı artırılmıştır.

\section{Ergonomik Değerlendirme ve REBA Yöntemi}

REBA metodu çalışanların bedensel duruşundan yola çıkarak maruz kaldıkları ergonomik yükü hesaplamayı amaçlayan Hignett ve McAtamney (2000) tarafından geliştirilen bir ergonomik değerlendirme yöntemdir. Yöntem özellikle manuel olarak yapılan görevlerin ergonomik riskinin değerlendirilmesinde çok etkilidir. REBA statik hareketleri dinamik değişimleri de göz önünde bulundurarak değerlendirebilme olanağı sağlar. Bu sayede REBA ile çalışanların vücut duruşunun ergonomik olarak değerlendirilmesi yapılmış ve ergonomik risk faktörü sayısal olarak elde edilmiş olur.

REBA skorunun hesaplanması için kısaca aşağıdaki dört adımlık algoritma kullanılabilir. Bunun yanı sıra Şekil 1'de REBA skorunu hesaplanması için gereken akışşeması verilmiştir.

\section{Adım 1: Görevin gözlemlenmesi}

Personel görevi yerine getirdiği esnada, vücut duruşu, ekipman kullanımı, görevin yerine getirilmesi için gerekli ekipmana ulaşılabilirlik, çalışma ortamı gibi birçok faktör açısından gözlemleyerek kayıtlar tutulur.

\section{Adım 2: Vücut duruşu seçimi}

REBA skorunu hesaplamak için her görev adına personelin vücut duruşunun tanımlanması gerekmektedir. Vücut duruşu belirlenirken en genel ve uzun süreli vücut duruşunun korunduğu yüksek kas gücü isteyen görevlere dikkat edilmelidir. Bir vücut duruşunun seçimi için bir veya birden fazla duruma dikkat etmek gerekebilir.

\section{Adım 3: Vücut duruşunun puanlanmasl}

Şekil 1'de gösterilen A grubu skoru personelin gövde, boyun ve bacaklarının pozisyonuna ve duruşuna göre Ek A'da verilen Tablo A'dan bir skor seçilir. B grubu olarak adlandırılan skor ise üst kol, alt kol ve bilekler ile ilgilidir ve e Ek A'da verilen Tablo B'den vücut duruşuna göre bir skor her bir görev için seçilir.

\section{Adım 4: İ̧slem Noktaları}

Bu adımda Tablo A'dan elde edilen skora yük/kuvvet skoru da eklenerek A skoru belirlenir. Yük skoru için personelin maruz kaldığı kuvvet yaklaşı 5 kilogramdan az ise 0,5 ile 10 kilogram arasında ise 1 ve 10 kilogramdan fazla ise 2 değeri olarak seçilmelidir. Tablo B skoruna kavram skoru eklenerek hesaplamalara devam edilir. Kavrama skoru görev yerine getirilirken iyi kavrama varsa 0, uygun ama ideal bir kavrama yoksa 1, kavrama uygun olmayacak kadar kötü ise 2 ve zor ve güvenli olmayan bir kavrama var ise 3 değeri ergonomi skoruna eklenir. Elde edilen A ve B skorları kullanılarak Ek A'da verilen Tablo C'den C skoru belirlenir. Elde edilen bu C 
skoruna Ek A'da verilen Tablo D'deki aktivite skoru da eklenerek toplam REBA skoru belirlenir. Ek A'da verilen Tablo E kullanılarak elde edilen REBA skorunun genel ergonomik risk skoru belirlenir.

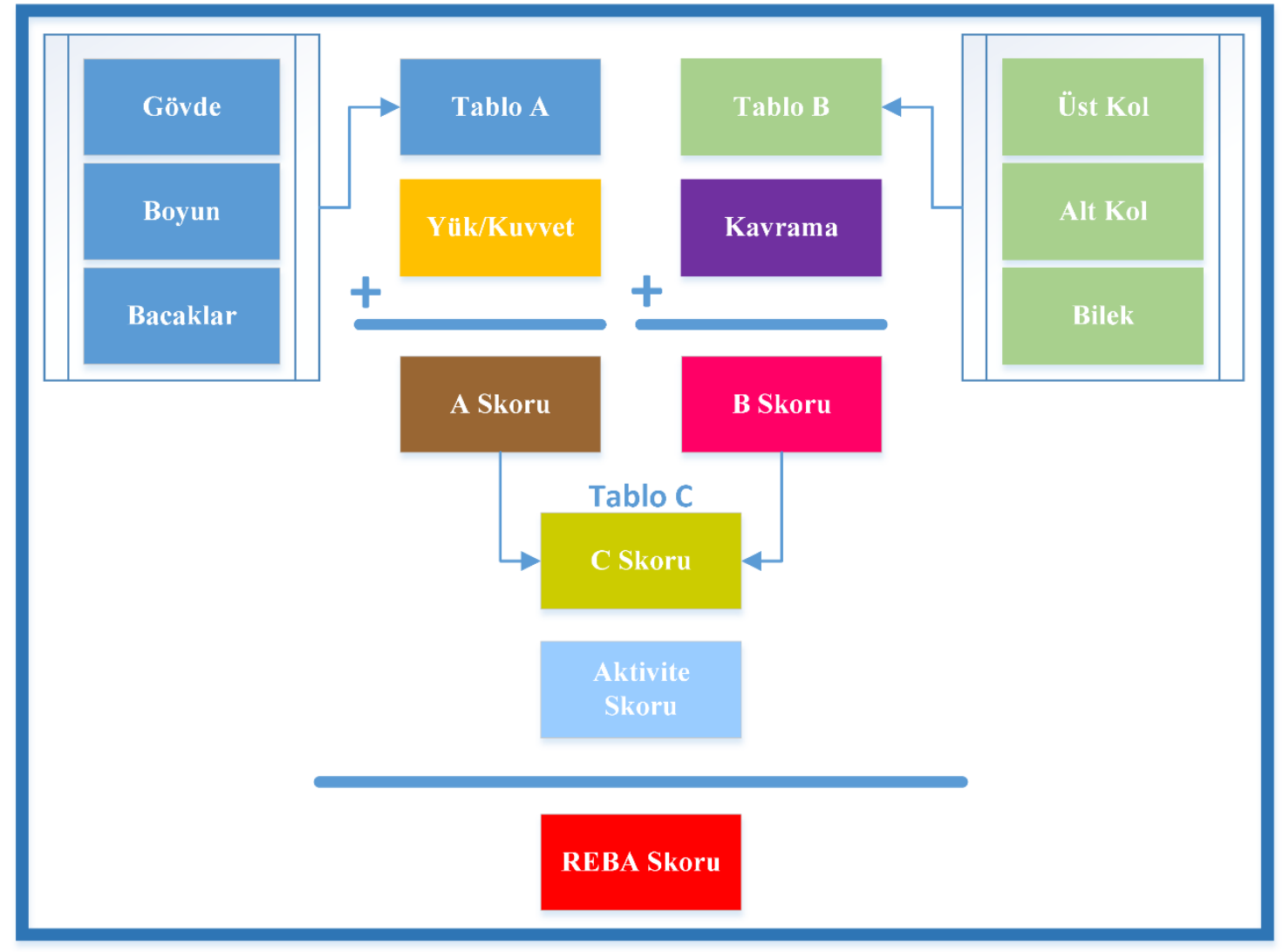

Şekil 1. REBA skoru hesaplama akışşeması

Her bir görev için REBA skoru yukarıda anlatılan adım adım algoritma ve Şekil 1 kullanılarak belirlenir. Elde edilecek bu REBA skorları önerilecek KP modelinde REBA A, B ve genel skor olmak üzere ergonomik kısıtlar olarak kullanılacaktır. Önerilen modelin amaç fonksiyonu bu skorlardan oluşacak sapma değerlerinin en küçüklenmesi olarak belirlenmiştir. Modelde üç skorun birden değerlendirilmesi personelin ergonomik açıdan vücut duruşundaki tüm organlara olan yükün daha dengeli dağılmasını sağlayacaktır.

\section{Problem Tanımı ve Önerilen Kısıt Programlama Modeli}

Bir personel görev çizelgeleme problemi $g$ adet görevin $p$ adet personele atanması ile ilgilidir. PGÇP, toplam boş zamanın en küçüklenmesi, personel yetkinlik dağılımını düzgünleştirmek gibi tek amaçlı olarak ele alınırken problemin uygulama alanına bağlı olarak birden fazla amacın dikkate alındığı çok amaçlı olarak da ele alınabilmektedir. Bu çalışmada önerilen modelde, REBA yöntemi ile personel üzerinde oluşacak A, B ve toplam ergonomik yüklerin en küçüklenmesini amaçlayan çok amaçlı bir problem dikkate alınmıştır. Model geliştirilirken dikkate alınan varsayımlar şu şekildedir:

- Bir personelin günlük maksimum çalışma süresi 510 dakikadır.

- Personel üzerindeki iş yükünü sınırlandırmak amacıyla bir personele en fazla altı adet görev atanabilmektedir.

- Personeller her görevi yapabilecek yetkinliğe sahiptir.

- Görevlerin gerçekleştirilme süresi önceden belirlenmiştir.

- İşletmenin süreçleri dikkate alınarak bir görevin yerine getirilmesi için gerekli personel sayısı dikkate alınmıştır.

- Her bir görevin ergonomik değerlendirilmesi yapılmış ve REBA yönteminden ileri gelen skorlar tespit edilmiştir.

- Problemde REBA skorlarından A, B ve toplam REBA skorunun en küçüklenmesi amaçlanmıştır.

Bahsedilen varsayımlar altında EPGÇP için önerilen KP modeli aşağıda verilmiştir. Model için gerekli olan notasyon şu şekildedir:

Indisler

$i=$ Personel 
$j, k=\mathrm{Görev}$

\section{Parametreler}

$p=$ Toplam personel sayıs1

$\bar{P}=$ Personel kümesi $(1,2, \ldots, p)$

$g=$ Toplam görev sayısı

$\bar{G}=$ Görev kümesi $(1,2, \ldots, g)$

$W=$ Günlük çalışma süresi $(510 \mathrm{dk})$

$G_{\max }=$ Bir personele atanabilecek maksimum görev sayısı $\left(G_{\max }=6\right)$

$P G$ Bir personelin yaptığı görev sırası kümesi $\left(1,2, \ldots, G_{\max }\right)$

$p_{j}=j$ görevi için gerekli personel sayısı

$t_{j}=j$ görevini gerçekleştirme süresi

$R_{j}=j$ görevinin REBA skoru

$A_{j}=j$ görevinin REBA A skoru

$B_{j}=j$ görevinin REBA B skoru

\section{Karar değişkenleri}

$x_{j k}=i$ personelinin $k$. sırada yapacağ görevin numarası, $i \in \bar{G}, k \in P G$

$d_{i 1}^{-}=i$ görevinin REBA skor amacından negatif sapma değeri

$d_{i 1}^{+}=i$ görevinin REBA skor amacından pozitif sapma değeri

$d_{i 2}^{-}=i$ görevinin REBA A skor amacından negatif sapma değeri

$d_{i 2}^{+}=i$ görevinin REBA A skor amacından pozitif sapma değeri

$d_{i 3}^{-}=i$ görevinin REBA B skor amacından negatif sapma değeri

$d_{i 3}^{+}=i$ görevinin REBA B skor amacından pozitif sapma değeri

$\operatorname{Min} \sum_{i \in G} d_{i 1}^{+}+d_{i 2}^{+}+d_{i 3}^{+}$

s.t.

$x_{i k} \geq 0$

$\forall i \in \bar{P}, k \in P G$

$x_{i k} \leq g$

$\forall i \in \bar{P}, k \in P G$

$\sum_{k \in P G}\left(x_{i k}=j\right) \cdot t_{j} \leq W$

$\forall i \in \bar{P}, j \in \bar{G}$

$\operatorname{count}\left(i \in \bar{G}, k \in P G, x_{i k} ; j\right)=p_{j}$

$\forall j \in \bar{G}$

$\operatorname{count}\left(k \in P G, x_{i k} ; j\right) \leq 1$

$\forall i \in \bar{P}, j \in \bar{G}$

$\sum_{j \in \bar{G}}\left(x_{i k}=j\right) \cdot t_{j} \cdot R_{j}-d_{i 1}^{+}+d_{i 1}^{-}=\sum_{j \in G}\left(x_{i k}=j\right) \cdot t_{j} \cdot 7 \quad \forall i \in \bar{P}, k \in P G$

$\sum_{j \in \bar{G}}\left(x_{i k}=j\right) \cdot t_{j} \cdot A_{j}-d_{i 2}^{+}+d_{i 2}^{-}=\sum_{j \in \bar{G}}\left(x_{i k}=j\right) \cdot t_{j} \cdot 5$

$\forall i \in \bar{P}, k \in P G$

$\sum_{j \in \bar{G}}\left(x_{i k}=j\right) \cdot t_{j} \cdot B_{j}-d_{i 3}^{+}+d_{i 3}^{-}=\sum_{j \in \bar{G}}\left(x_{i k}=j\right) \cdot t_{j} \cdot 5 \quad \forall i \in \bar{P}, k \in P G$ 

$\left(d_{i 1}^{-}>0\right)+\left(d_{i 1}^{+}>0\right) \leq 1$
$\forall i \in \bar{P}$
$\left(d_{i 2}^{-}>0\right)+\left(d_{i 2}^{+}>0\right) \leq 1$
$\forall i \in \bar{P}$
$\left(d_{i 3}^{-}>0\right)+\left(d_{i 3}^{+}>0\right) \leq 1$
$\forall i \in \bar{P}$
$x_{i k} \in \bar{G}$ ve tamsayl
$\forall i \in \bar{P}, k \in P G$

Eşitlik (1) önerilen KP modelinin amacı olarak tanımlanmıştır. EPGÇP'de amaç personellerin maruz kaldığı ergonomik risk yüklerini azaltmaktır. Önerilen model amaç programlama tabanlı bir çok amaçlı model olduğundan görevlerin REBA skorlarından pozitif sapmayı en küçüklemeyi amaç edinmiştir. Bu sayede hem personel uzuvları üzerindeki ergonomik yükün dengeli dağılımı elde edilmiş hem de toplam REBA puanı amacı sayesinde personel üzerindeki yük ve kavrama dengesi elde edilmiş olacaktır. REBA skorlarındaki pozitif sapmalar REBA skorunda artışa neden olacağından küçüklenmesi gerekmektedir. Eşitlik (2) bir personelin $k$ 'inci sırada yapacağı görev numarasının sıfırdan büyük olmasını garanti eder. Benzer şekilde Eşitlik (3) personelin yerine getireceği görev numarasının toplam görev sayısından büyük olmamasını sağlar. Başka bir deyişle bu iki eşitlik karar değişkeninin çözüm kümesi aralığını tanımlar. Eşitlik (4) personellere görev atanırken günlük toplam çalışma süresinden daha fazla süre görev atanmasını engeller. $\mathrm{Bu}$ eşitlikte yer alan $\left(x_{i k}=j\right)$ mantıksal ifadesi eğer $i$ personelinin $k$ sıradaki yapacağ göreve $j$ görevi atand ise ifadesinin mantıksal sınamasıdır. Bu ifade bir değerini aldığında görevin gerçekleştirilme süresi ile çarpılır ve bu hesap tüm personel için tekrarlanarak günlük çalışma süresi ile sınırlandırır. Eşitlik (5) bir görevin yerine getirilmesi için gerekli olan personel sayısını belirler. Eşitlikte yer alan count () KP çözücüsünde tanımlanmış bir fonksiyondur ve $x_{i k}$ karar değişkeninin sonucunun $j$ 'ye eşit olduğu toplam sonuç sayısını döndürür. Eşitlik (6) her bir görevin sadece bir personele atanmasını garanti eder. İşletmedeki görevler ve bu görevlerin ergonomik riskleri gözlemlendiğinde, personel üzerine yüklenecek ergonomik riskin de belirli sınırlar arasında kalmasına karar verilmiş̦tir. Bu amaçla Eşitlik (7) ile bir personel üzerindeki toplam REBA puanının yedi ile sınırlandırılması sağlanmıştır. Benzer şekilde Eşitlik (8) ve Eşitlik (9) sırası ile personel üzerindeki ergonomik yükü sınırlandırmak amacıyla REBA A ve REBA B skorlarını beş puan ile sınırlandırır. Eşitlik (7), Eşitlik (8) ve Eşitlik (9) amaç fonksiyonunu etkileyen kısıtlardır ve bu kısıtlardan oluşan negatif ve pozitif sapmalar personel üzerindeki ergonomik yükün hesaplanmasını sağlayacaktır. Eşitlik (10), Eşitlik (11) ve Eşitlik (12) amaç fonksiyonunu etkileyen kısıtlardan oluşan negatif ve pozitif sapmalardan sadece birinin pozitif değer almasını sağlarlar. Bu kısıtlar ile personel ergonomik yükü için bir denge kurulmaya çalışılmıştır. Karar değişkeninin tanım kümesi Eşitlik (13) ile belirlenmiştir.

\section{Vaka Çalışması ve Deneysel Sonuçlar}

$\mathrm{Bu}$ bölümde orta gerilim sigorta (OGS) üretimi yapan bir firmadan elde edilen gerçek veriler ile önerilen modelin etkinliği değerlendirilmiştir. Ayrıca modelin vaka analizi sonuçları bu bölümde rapor edilmiştir. Deney sonuçları literatürde PGÇP ve EPGÇP üzerine yapılmış olan sırasıyla Pınarbaşı ve Alakaş (2020) ve Alakaş vd. (2020) çalışmalarının sonuçları ile karşılaş̧ırmalı olarak verilmiş̧ir. Bu çalışmalardan Pınarbaşı ve Alakaş (2020) PGÇP'yi ergonomik risk faktörlerini dikkate almaksızın matematiksel programlama ile çözerken, Alakaş vd. (2020) EPGÇP'yi amaç programlama yaklaşımı ile çözmüşlerdir.

\subsection{Orta Gerilim Sigorta Üretimi}

Orta gerilim sigortalar elektrik trafolarından büyük işletmelerin elektrik tesisatlarına kadar birçok elektriksel donanımı yüksek akımlardan korumak amacıyla kullanılan bir akım kesme elemanıdır. Temel olarak seramik bir boru içerisine yerleştirilmiş taşıyıcı isimli üzerinde elektriksel devrenin sarılı olduğu bir elemandan oluşan yapıya sahiptir. Boru uçlarında bulunan bakır temelli bir malzemeden oluşan kapaklar vasitasıyla sisteme entegre edilirler. OGS'ler hem etkili koruması hem de ucuz olması nedeniyle elektriksel altyapılarda sıklıkla tercih edilen bir elemandır.

Elektriksel sistemde çok önemli bir görevi yerine getirmesi sebebiyle OGS'lerin belirli kalite şartlarında ve alanında yetkin personeller tarafindan üretilmesi gerekmektedir. Geleneksel bir OGS üretiminde şu dört ana sürecin var olması gerekmektedir: çamurhane, fırınlama ve kesme, ara ürün imalatı ve son montaj. Bu dört bölümün her biri kendi içinde uzmanlık gerektiren üretim süreçleri içermektedir. OGS üretimi çamurhane bölümü olarak adlandırılan ve sigortanın dış ve iç bölümlerinde yer alan seramik boru ve taşıyıcı malzemelerinin üretiminin yapıldığı bölümdür. Seramik malzemeler çeşitli toprak hammaddelerinin bir araya getirilerek değirmenlerde karıştırılması ve çamur halinden boru ve taşıyıcı yarı ürünlerine presler vasıtasıyla şekillendirilirler. Pişirilmemiş boru ve taşıyıcı mamulleri firın bölümünde belirli sıcaklıklarda pişirildikten sonra kesme bölümünde kesilerek istenilen şartlara göre hazırlanırlar. OGS'ler temel ara ürünler olan boru ve taşıyıcı mamulleri yanı sıra kapaklar ve iç devre elemanları gibi birçok ara ürünün bir araya getirilmesi ile meydana getirilirler. Vaka analizinde OGS üretimi yapan firma bu tür ara ürünleri de kendi bünyesinde üretmektedir. $\mathrm{Bu}$ sebeple ara ürünlerin de hassas üretim teknikleri ile üretimini sağlamak adına personel görev çizelgesinin etkin bir şekilde oluşturulması gerekmektedir. Montaj bölümü kendinden önceki bölümlerde üretilen tüm ara ürünlerin bir araya getirilerek ana ürün olan OGS'nin meydana getirildiği bölümdür. Bu bölümde kendi içerisinde uzmanlık isteyen hassas üretim süreçleri gerektirdiğinden bu bölümün personel çizelgesi de bu çalışmada dikkate alınmıştır.

Tanımlanmış bu süreçleri içeren OGS üretimi yapan firmada toplam 43 görev için 12 personelin görevlendirilmesi gerekmektedir. OGS'lerin hassas üretimi gereği belirli sayıda personelin belirli sayıda görevi bireysel veya kolektif olarak yerine getirmesi gerekmektedir. OGS üretimi için gerekli olan üretim bölümlerine ait görevler ve bu görevlere ait veriler Tablo 2'de verilmiştir. 
Tablo 2. OGS üretimi için gerekli olan veriler

\begin{tabular}{|c|c|c|c|c|c|c|c|c|c|}
\hline $\begin{array}{l}\text { Üretim } \\
\text { Bölümü }\end{array}$ & $\begin{array}{c}\text { Görev } \\
\text { No }\end{array}$ & Görev & Süre & $\begin{array}{c}\text { Gereken } \\
\text { Personel } \\
\text { Sayısı }\end{array}$ & $\begin{array}{l}\text { Üretim } \\
\text { Bölümü }\end{array}$ & $\begin{array}{c}\text { Görev } \\
\text { No }\end{array}$ & Görev & Süre & $\begin{array}{c}\text { Gereken } \\
\text { Personel } \\
\text { Sayisı } \\
\end{array}$ \\
\hline \multirow{12}{*}{ 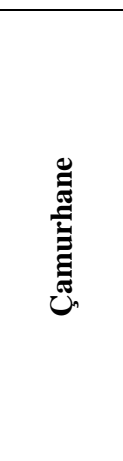 } & 1 & Çamur Hammadde Tartım & 90 & 2 & \multirow{10}{*}{ 泀 } & 23 & Kontak Başlık Kesme & 66 & 2 \\
\hline & 2 & Değirmen Doldurma & 30 & 4 & & 24 & Kontak Başlık Şekillendirme & 133 & 1 \\
\hline & 3 & Değirmen Su Verme & 30 & 1 & & 25 & Kontak Başlık Kanal Açma & 133 & 1 \\
\hline & 4 & Çamur Eleme & 120 & 1 & & 26 & Yay Sarma & 166 & 1 \\
\hline & 5 & Çamur Tanka Basma & 30 & 1 & & 27 & Tarak Presleme & 33 & 2 \\
\hline & 6 & Pres Boşaltma & 30 & 2 & & 28 & Delikli Kapak Presleme & 20 & 1 \\
\hline & 7 & Sır Hammadde Tartım & 15 & 1 & & 29 & Kum Sonlandırıcı Presleme & 20 & 1 \\
\hline & 8 & Sir Değirmen Doldurma & 15 & 2 & & 30 & Son Kapak Presleme & 20 & 1 \\
\hline & 9 & Sir Eleme & 15 & 1 & & 31 & Tarak Takma & 130 & 1 \\
\hline & 10 & Srr Ayarlama ve Renklendirme & 60 & 2 & & 32 & Gösterge Elemanı Yapma & 400 & 1 \\
\hline & 11 & Dış Gövde Şekillendirme & 191 & 2 & \multirow{11}{*}{ 苛 } & 33 & Erime Hattı Sarma & 253 & 1 \\
\hline & 12 & Taşıyıcı Sekillendirme & 102 & 2 & & 34 & Kontak Başlık Sıvama & 253 & 1 \\
\hline \multirow{4}{*}{ 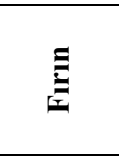 } & 13 & Dış Gövde Rötuşlama & 45 & 2 & & 35 & Taşıyıcı Puntalama & 166 & 1 \\
\hline & 14 & Dış Gövde Sırlama & 45 & 2 & & 36 & Gösterge Elemanı Takma & 253 & 1 \\
\hline & 15 & Fırın Yükleme & 55 & 3 & & 37 & Tarak Puntalama & 66 & 1 \\
\hline & 16 & Fırın Boşaltma & 30 & 4 & & 38 & Delikli Kapak Sivama & 100 & 1 \\
\hline \multirow{5}{*}{ 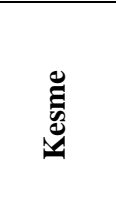 } & 17 & Diş Gövde Kesme & 195 & 1 & & 39 & Kumlama & 33 & 1 \\
\hline & 18 & Taşıyıcı Kesme & 28 & 1 & & 40 & Kum Sonlandırma Takma & 66 & 1 \\
\hline & 19 & Diş Gövde Kanal Açma & 155 & 1 & & 41 & Son Kapak Sivama & 66 & 1 \\
\hline & 20 & Taşıyıcı Kanal Açma & 51 & 1 & & 42 & Etiketleme ve Paketleme & 233 & 1 \\
\hline & 21 & Dış Gövde Kalite Ayrım & 155 & 1 & & 43 & Kolileme ve İstifleme & 19 & 1 \\
\hline
\end{tabular}

Bu çalışmada PGÇP ergonomik risk faktörlerini de dikkate alarak çözülmüştür. Tablo 3’te, OGS üretiminde yer alan görevlere ait Şekil 1'de verilen REBA hesaplama akışına göre uzmanlar ve firma yöneticileri tarafından belirlenmiş skorlar verilmiştir. Tablo 3 'te görülmektedir ki OGS üretiminde genellikle çamurhane ve firın/kesme bölümlerindeki görevler ergonomik açıdan oldukça risklidir. Ürünler montaj bölümüne kesilmiş ve gerekli ölçülere getirilmiş olarak sevk edildiğinden ve firma montaj hattını uygun fiziksel şartlara göre tasarladığından montaj bölümüne ait görevlerin ergonomik riski nispeten düşüktür. Ancak bu bölümdeki paketleme ve kolileme görevleri özellikle ürünlerin ağırlıkları nedeniyle ergonomik açıdan yüksek riskili olarak belirlenmiştir.

\subsection{Sayısal Sonuçlar ve Tartışma}

Bölüm 5.1'de personeller ve yerine getirilecek görevler için gerekli olan görev süreleri, REBA skorları ve görev için gerekli personel görev sayısı gibi teknolojik kısıt verileri verilmiştir. Elde edilen bu veriler ile önerilen KP modeli çalıştırılmışıı. Modelin test edilmesi için IBM ILOG CP Optimizer paket programı kullanılmıştır. Belirtilen veriler ışığında modelin toplu sonuçları Tablo 4'te rapor edilmiştir.

Sonuçlar değerlendirildiğinde tüm görevlerin yerine getirilmesi için gereken personel sayısı kadar atama yapılmıştır. Görevlerin toplam REBA puanları değerlendirildiğinde çamurhane bölümüne ait görevlerin ergonomik risklerinin fazla olduğu görülmüştür. Bu durum Tablo 3'te REBA skorları belirlenirken uzmanlar tarafindan da ön görülen sonuçlar ile örtüşmektedir. Tablo 4'te her bir personele atanan toplam görev sayısı açısından değerlendirildiğinde firmada yerine getirilmesi gereken 61 görevin tamamına bir personel atanmıştır. Beş personele atanması gereken toplam altı görevin tamamı atanırken, dört personele beş görev, iki personele dört ve bir personele üç görev ataması yapılmıştır. Personeller toplam çalışma zamanı açısından değerlendirildiğinde iki personele 509 dakika çalışma zamanı ile neredeyse günlük çalışma zamanı sınırının tamamı kadar süre görev atandığı görülmektedir. Diğer personellere günlük çalışma zamanı sınırına uygun bir şekilde, model boş zamanları dengeli bir şekilde atanmıştır. Ancak personel 2'ye 228 dakika ile en az toplam çalışma zamanı atanmıştır. Çalışma zamanı dengesinde en az süreyi temsil eden bu atamanın nedeni firmanın mazeret izni gibi nedenler ile aniden gerçekleşen personel eksikliklerinde görevlerin aksamaması adına gerekli işçi sayısını bir yedek işçi fazla hesaplamasıdır. Bu sayede izinli bir personelin görevlerinin toplam çalışma zamanı az olan personellere verilmesine imkan verilerek işin aksamaması sağlanmaktadır. Yani günlük çalışma zamanından az çalışma süresi olan personellerin boş zamanları bu şekilde değerlendirilmektedir.

Personeller üzerine oluşan ortalama REBA skoru açısından değerlendirildiğinde önerilen modelde yer alan kısıt (7) nedeniyle ortalama REBA skoru yedi ile sınırlandırılmıştır. Bir personel dışında diğer tüm personelin belirlenen ergonomik yük skoru sınırında veya göreceli olarak üzerinde bir skor elde ettiği görülmüștür. Personel iki ve dört sırasıyla 7.539 ve 7.540 skorları ile belirlenen ergonomik yük skoru açısından en yüksek riski barındırmaktadırlar. İlgili personelin ergonomik yüklerini azaltmak veya etki eden yükten görecekleri zararı azaltmak adına görevin yerine getirilmesi için daha etkili araç ve gereçlerin kullanılması veya geliştirilmesi önerilebilir. 
Tablo 3. Görevlere ait REBA skorları

\begin{tabular}{|c|c|c|c|c|c|c|c|c|c|c|c|c|c|}
\hline \multirow{2}{*}{ Görev } & \multicolumn{3}{|c|}{ Grup A } & \multicolumn{3}{|c|}{ Grup B } & \multirow{2}{*}{$\begin{array}{c}\text { Yük/ } \\
\text { Kuvvet }\end{array}$} & \multirow{2}{*}{ Kavrama } & \multirow{2}{*}{ Hareket } & \multirow{2}{*}{$\begin{array}{c}\text { A } \\
\text { skoru }\end{array}$} & \multirow{2}{*}{$\begin{array}{c}\text { B } \\
\text { skoru }\end{array}$} & \multirow{2}{*}{$\begin{array}{c}\text { C } \\
\text { skoru }\end{array}$} & \multirow{2}{*}{$\begin{array}{r}\text { REBA } \\
\text { skoru }\end{array}$} \\
\hline & Gövde & Boyun & Bacak & Üst Kol & Alt Kol & Bilek & & & & & & & \\
\hline Çamur Hammadde Tartım & 4 & 2 & 3 & 5 & 2 & 2 & 3 & 1 & 2 & 10 & 9 & 14 & 14 \\
\hline Değirmen Doldurma & 4 & 3 & 4 & 5 & 2 & 3 & 3 & 1 & 3 & 12 & 9 & 15 & 15 \\
\hline Değirmen Su Verme & 2 & 1 & 1 & 1 & 1 & 1 & 0 & 0 & 0 & 2 & 1 & 1 & 1 \\
\hline Çamur Eleme & 1 & 1 & 1 & 1 & 1 & 1 & 0 & 0 & 0 & 1 & 1 & 1 & 1 \\
\hline Çamur Tanka Basma & 1 & 1 & 1 & 1 & 1 & 1 & 2 & 0 & 0 & 3 & 1 & 2 & 2 \\
\hline Pres Boşaltma & 3 & 3 & 3 & 4 & 2 & 2 & 3 & 2 & 3 & 10 & 8 & 15 & 15 \\
\hline Sır Hammadde Tartım & 4 & 2 & 4 & 5 & 2 & 2 & 3 & 1 & 3 & 11 & 9 & 15 & 15 \\
\hline Sır Değirmen Doldurma & 4 & 3 & 3 & 1 & 2 & 3 & 3 & 1 & 3 & 11 & 4 & 14 & 14 \\
\hline Sir Eleme & 1 & 1 & 1 & 1 & 1 & 1 & 0 & 0 & 0 & 1 & 1 & 1 & 1 \\
\hline Sır Ayarlama ve Renklendirme & 2 & 2 & 1 & 2 & 2 & 1 & 3 & 2 & 1 & 6 & 4 & 8 & 8 \\
\hline Dış Gövde Şekillendirme & 3 & 3 & 1 & 4 & 2 & 2 & 2 & 3 & 3 & 7 & 9 & 13 & 13 \\
\hline Taşıyıcı Şekillendirme & 3 & 3 & 1 & 4 & 2 & 2 & 2 & 3 & 3 & 7 & 9 & 13 & 13 \\
\hline Dış Gövde Rötuşlama & 2 & 2 & 1 & 3 & 2 & 3 & 2 & 0 & 3 & 5 & 5 & 9 & 9 \\
\hline Diş Gövde Sırlama & 4 & 3 & 1 & 3 & 2 & 2 & 2 & 0 & 2 & 8 & 5 & 12 & 12 \\
\hline Fırın Yükleme & 2 & 2 & 1 & 5 & 2 & 3 & 3 & 0 & 3 & 6 & 8 & 12 & 12 \\
\hline Fırın Boşaltma & 2 & 2 & 1 & 5 & 2 & 3 & 3 & 0 & 3 & 6 & 8 & 12 & 12 \\
\hline Dış Gövde Kesme & 1 & 1 & 1 & 2 & 2 & 2 & 2 & 0 & 0 & 3 & 3 & 3 & 3 \\
\hline Taşıyıcı Kesme & 1 & 1 & 1 & 2 & 2 & 2 & 2 & 0 & 0 & 3 & 3 & 3 & 3 \\
\hline Diş Gövde Kanal Açma & 1 & 1 & 1 & 2 & 2 & 2 & 2 & 0 & 0 & 3 & 3 & 3 & 3 \\
\hline Taşıyıcı Kanal Açma & 1 & 1 & 1 & 2 & 2 & 2 & 2 & 0 & 0 & 3 & 3 & 3 & 3 \\
\hline Diş Gövde Kalite Ayrım & 3 & 2 & 1 & 3 & 2 & 3 & 2 & 0 & 2 & 6 & 5 & 10 & 10 \\
\hline Taşıyıcı Kalite Ayrım & 3 & 2 & 1 & 3 & 2 & 3 & 2 & 0 & 2 & 6 & 5 & 10 & 10 \\
\hline Kontak Başlık Kesme & 4 & 2 & 1 & 2 & 2 & 2 & 0 & 0 & 1 & 5 & 3 & 5 & 5 \\
\hline Kontak Başlık Şekillendirme & 2 & 2 & 1 & 2 & 1 & 2 & 0 & 0 & 0 & 3 & 2 & 3 & 3 \\
\hline Kontak Başlık Kanal Açma & 2 & 2 & 1 & 3 & 2 & 2 & 0 & 0 & 0 & 3 & 5 & 4 & 4 \\
\hline Yay Sarma & 2 & 1 & 1 & 1 & 1 & 3 & 0 & 0 & 1 & 2 & 2 & 3 & 3 \\
\hline Tarak Presleme & 2 & 2 & 1 & 2 & 1 & 2 & 0 & 0 & 0 & 3 & 2 & 3 & 3 \\
\hline Delikli Kapak Presleme & 2 & 2 & 1 & 2 & 1 & 2 & 0 & 0 & 0 & 3 & 2 & 3 & 3 \\
\hline Kum Sonlandırıcı Presleme & 2 & 2 & 1 & 2 & 1 & 2 & 0 & 0 & 0 & 3 & 2 & 3 & 3 \\
\hline Son Kapak Presleme & 2 & 2 & 1 & 2 & 1 & 2 & 0 & 0 & 0 & 3 & 2 & 3 & 3 \\
\hline Tarak Takma & 2 & 1 & 1 & 1 & 2 & 3 & 0 & 0 & 1 & 2 & 3 & 3 & 3 \\
\hline Gösterge Elemanı Yapma & 1 & 3 & 1 & 1 & 2 & 2 & 0 & 0 & 0 & 3 & 2 & 3 & 3 \\
\hline Erime Hattı Sarma & 1 & 1 & 1 & 1 & 1 & 2 & 1 & 2 & 2 & 2 & 4 & 5 & 5 \\
\hline Kontak Başlık Sıvama & 1 & 1 & 1 & 1 & 1 & 1 & 1 & 1 & 0 & 2 & 2 & 2 & 2 \\
\hline Taşıyıcı Puntalama & 1 & 2 & 1 & 1 & 1 & 3 & 1 & 1 & 1 & 2 & 3 & 3 & 3 \\
\hline Gösterge Elemanı Takma & 3 & 3 & 2 & 2 & 2 & 3 & 1 & 1 & 2 & 7 & 5 & 11 & 11 \\
\hline Tarak Puntalama & 1 & 2 & 2 & 1 & 1 & 3 & 1 & 1 & 1 & 3 & 3 & 4 & 4 \\
\hline Delikli Kapak Sıvama & 1 & 1 & 1 & 1 & 1 & 1 & 1 & 1 & 0 & 2 & 2 & 2 & 2 \\
\hline Kumlama & 1 & 1 & 1 & 1 & 1 & 1 & 2 & 1 & 1 & 3 & 2 & 4 & 4 \\
\hline Kum Sonlandırma Takma & 2 & 1 & 1 & 1 & 1 & 1 & 2 & 0 & 0 & 4 & 1 & 3 & 3 \\
\hline Son Kapak Sivama & 1 & 1 & 1 & 1 & 1 & 1 & 2 & 0 & 0 & 3 & 1 & 2 & 2 \\
\hline Etiketleme ve Paketleme & 3 & 2 & 2 & 3 & 2 & 3 & 2 & 1 & 1 & 7 & 6 & 10 & 10 \\
\hline Kolileme ve İstifleme & 5 & 3 & 3 & 4 & 2 & 3 & 3 & 1 & 3 & 12 & 8 & 15 & 15 \\
\hline
\end{tabular}

Önerilen KP modeli sonuçları EPGÇP için matematiksel model önerisinde bulunarak çözüm geliştiren Alakaş vd. (2020) çalışması sonuçları ile karşılaştııılmıştır. Bu çalışmada elde edilen sonuçlar Alakaş vd. (2020) çalışmasının sonuçları ile aynıdır. Bu durum önerilen KP modelinin etkili çözüm ürettiğinin bir göstergesidir.

Tablo 5'te verilen sonuçlar ise EPGÇP'yi ergonomik kısıtları göz önüne almaksızın ele alan son yıllardaki bir çalışma olan Pınarbaşı ve Alakaş (2020) çalışması ile karşılaştırmalı sonuçları içermektedir. Bu karşılaştırmadaki amaç ergonomik yüklerin personel görev ataması sonuçlarındaki etkisini incelemektir. Önerilen KP modeli Pınarbaşı ve Alakaş (2020) çalışmasına göre çalışılan zaman açısından değerlendirildiğinde önerilen modelin daha dengeli bir atama yaptığı söylenebilir. Benzer şekilde ilgili çalışmalar bir personele atanan ortalama görev sayısı açısından değerlendirildiğinde, KP modelinin daha dengeli atama yaptığı görülmektedir. Pınarbaşı ve Alakaş (2020) çalışmasında toplam iş yükünün çoğunun ilk sekiz personele atandığı görülürken KP modelinde görev dağılımı daha adil yapılabilmiştir. Ayrıca bu çalışmanın bir katkısı da personelin ergonomik risk yükünü de göz önüne almasıdır. Bu çalışma da göstermiştir ki ergonomik yüklerin personel görev atamasında dikkate alınması daha etkili, dengeli ve etkin bir görev çizelgesinin oluşmasını sağlamıştır. 
Tablo 4. Personel görev çizelgeleme sonuçları

\begin{tabular}{|c|c|c|c|c|c|c|c|c|c|c|c|c|c|c|}
\hline Görev & 1 & 2 & 3 & 4 & 5 & 6 & 7 & 8 & 9 & 10 & 11 & 12 & REBA & $\begin{array}{c}\text { Toplam } \\
\text { Personel Sayısı }\end{array}$ \\
\hline Çamur Hammadde Tartım & & & & & & & 1 & 1 & & & & & 14 & 2 \\
\hline Değirmen Doldurma & 1 & & & 1 & & & & 1 & & & 1 & & 15 & 4 \\
\hline Değirmen $\mathrm{Su}$ Verme & & & & & & & & & & & & 1 & 1 & 1 \\
\hline Çamur Eleme & & & & & & & & & & 1 & & & 1 & 1 \\
\hline Çamur Tanka Basma & & 1 & & & & & & & & & & & 2 & 1 \\
\hline Pres Boşaltma & 1 & & & 1 & & & & & & & & & 15 & 2 \\
\hline Sir Hammadde Tartım & & & & 1 & & & & & & & & & 15 & 1 \\
\hline Sır Değirmen Doldurma & & & 1 & 1 & & & & & & & & & 14 & 2 \\
\hline Sir Eleme & 1 & & & & & & & & & & & & 1 & 1 \\
\hline Sır Ayarlama ve Şekillendirme & & 1 & & & & & & & 1 & & & & 8 & 2 \\
\hline D1ş Gövde Şekillendirme & & & & & & 1 & & & & 1 & & & 13 & 2 \\
\hline Taşıyıcı Şekillendirme & & & & & & & & & 1 & & & 1 & 13 & 2 \\
\hline D1ş Gövde Rötuşlama & & & & & & & 1 & & & & 1 & & 9 & 2 \\
\hline D1ş Gövde Sırlama & & & & & & & & & 1 & 1 & & & 12 & 2 \\
\hline Fırın Yükleme & & 1 & & & & & 1 & 1 & & & & & 12 & 3 \\
\hline Fırın Boşaltma & 1 & 1 & & & 1 & & & 1 & & & & & 12 & 4 \\
\hline Diş Gövde Kesme & & & & & & & & & 1 & & & & 3 & 1 \\
\hline Taşıyıcı Kesme & & & & & & & & & 1 & & & & 3 & 1 \\
\hline Diş Gövde Kanal Açma & & & & & & & 1 & & & & & & 3 & 1 \\
\hline Taşıyıcı Kanal Açma & & & & & & & & & & & 1 & & 3 & 1 \\
\hline D1ş Gövde Kalite Kontrol & & & & & & & & & & & 1 & & 10 & 1 \\
\hline Taşıyıcı Kalite Ayrım & & & & & & & & & & & & 1 & 10 & 1 \\
\hline Kontak Başlık Kesme & & & & & & 1 & & & & & & 1 & 5 & 2 \\
\hline Kontak Başlik Şekillendirme & & & & & & & & & & 1 & & & 3 & 1 \\
\hline Kontak Başlık Kanal Açma & & & & & & & & & & & 1 & & 4 & 1 \\
\hline Yay Sarma & & & & & & 1 & & & & & & & 3 & 1 \\
\hline Tarak Presleme & & 1 & & & & & & & & & 1 & & 3 & 2 \\
\hline Delikli Kapak Presleme & & & & & & & & & & & & 1 & 3 & 1 \\
\hline Kum Sonlandırıcı Presleme & & & & & & & & & & 1 & & & 3 & 1 \\
\hline Son Kapak Presleme & & 1 & & & & & & & & & & & 3 & 1 \\
\hline Tarak Takma & & & 1 & & & & & & & & & & 3 & 1 \\
\hline Gösterge Elemanı Yapma & & & & 1 & & & & & & & & & 3 & 1 \\
\hline Erime Hattı Sarma & 1 & & & & & & & & & & & & 5 & 1 \\
\hline Kontak Başlık Sıvama & & & & & & & & 1 & & & & & 2 & 1 \\
\hline Taşıyıcı Puntalama & & & & & 1 & & & & & & & & 3 & 1 \\
\hline Gösterge Elemanı Takma & & & 1 & & & & & & & & & & 11 & 1 \\
\hline Tarak Puntalama & & & & & & & 1 & & & & & & 4 & 1 \\
\hline Delikli Kapak Sıvama & & & 1 & & & & & & & & & & 2 & 1 \\
\hline Kumlama & & & & & & & 1 & & & & & & 4 & 1 \\
\hline Kum Sonlandırma Takma & & & & & & 1 & & & & & & & 3 & 1 \\
\hline Son Kapak Sivama & & & & & & & & & & & & 1 & 2 & 1 \\
\hline Etiketleme ve Paketleme & & & & & 1 & & & & & & & & 10 & 1 \\
\hline Kolileme ve İstifleme & & & & 1 & & & & & & & & & 15 & 1 \\
\hline Toplam Çalışma & 358 & 228 & 498 & 509 & 429 & 489 & 444 & 458 & 430 & 509 & 447 & 335 & & \\
\hline Toplam Görev Sayısı & 5 & 6 & 4 & 6 & 3 & 4 & 6 & 5 & 5 & 5 & 6 & 6 & & \\
\hline Ortalama REBA Skoru & 7.095 & 7.539 & 7.195 & 5.540 & 7.431 & 7.176 & 7.176 & 7.066 & 7.012 & 7.077 & 7.134 & 7.128 & & \\
\hline
\end{tabular}

Yapılan çalışmanın firmaya olan katkısı değerlendirildiğinde, görev atamalarının henüz göreve başlanmadan önce belirlenmiş olması personelin iş yeri memnuniyeti, motivasyonu ve çalışma azmi açısından olumlu katkılar sunacaktır. İşletmenin personel görev ataması ve çizelgelemesi için öngörüde bulunacağı bir matematiksel altyapı sunulabilmiştir. Personellerin ergonomik açıdan değerlendirilmiş bir şekilde görev edinmesi firmanın mesleki hastalıklar riskinin düşmesine de neden olacaktır. Benzer etki personel sağlığı üzerinde de görülecektir. Çalışma ile elde edilen sonuçların değerlendirilmesi ile firma ergonomik riskleri azaltmak için bir yol haritasına da kavuşmuş olacaktır. 
Tablo 5. Pınarbaşı ve Alakaş (2020) ve KP modeli sonuçlarının karşılaştırılması

\begin{tabular}{|c|c|c|c|c|c|c|}
\hline \multirow[b]{2}{*}{ Personel } & \multicolumn{3}{|c|}{ Pınarbaşı ve Alakaş (2020) } & \multicolumn{3}{|c|}{ KP Modeli } \\
\hline & $\begin{array}{l}\text { Çalışılan } \\
\text { Zaman }\end{array}$ & $\begin{array}{l}\text { Boş } \\
\text { Zaman }\end{array}$ & $\begin{array}{l}\text { Atanan Toplam } \\
\text { Görev Sayıs1 }\end{array}$ & $\begin{array}{l}\text { Çalışılan } \\
\text { Zaman }\end{array}$ & $\begin{array}{l}\text { Boş } \\
\text { Zaman }\end{array}$ & $\begin{array}{l}\text { Atanan Toplam } \\
\text { Görev Sayıs1 }\end{array}$ \\
\hline 1 & 240 & 270 & 6 & 358 & 152 & 5 \\
\hline 2 & 285 & 225 & 6 & 228 & 282 & 6 \\
\hline 3 & 489.59 & 20.41 & 6 & 498 & 12 & 4 \\
\hline 4 & 417.92 & 92.08 & 6 & 509 & 1 & 6 \\
\hline 5 & 491.67 & 18.33 & 6 & 429 & 81 & 3 \\
\hline 6 & 486.68 & 23.32 & 6 & 489 & 21 & 4 \\
\hline 7 & 336.68 & 173.32 & 6 & 444 & 66 & 6 \\
\hline 8 & 382.01 & 127.99 & 6 & 458 & 52 & 5 \\
\hline 9 & 502.02 & 7.98 & 5 & 430 & 80 & 5 \\
\hline 10 & 506.17 & 3.83 & 4 & 509 & 1 & 5 \\
\hline 11 & 506.68 & 3.32 & 2 & 447 & 63 & 6 \\
\hline 12 & 500 & 10 & 2 & 335 & 175 & 6 \\
\hline
\end{tabular}

\section{Sonuç}

Bu çalışmada personel görev çizelgeleme problemi ergonomik risk skorlarını da dikkate alarak çözülmüştür. Problemin çözümü için bir kısıt programlama modeli önerilmiştir. Geliştirilen KP modeli REBA metodu ile elde edilen üç farklı REBA skorunun amaç programlama tabanlı bir çok amaçlı amaç fonksiyonunu en iyilemek üzere kurulmuştur. Model ergonomik kısıtların yanı sıra bir personele atanması gereken toplam görev sayısı, personel üzerindeki ergonomik risk yükü, günlük toplam çalışma zamanı gibi firmanın teknolojik kısıtlarını da içermektedir. Önerilen model orta gerilim sigorta üretimi yapan bir firmadan elde edilen gerçek veriler ile test edilmiştir. Görevler için ergonomik risk yükünün değerlendirilmesi için REBA metodundan faydalanılmıştır. Görev REBA skorlarının belirlenmesinde, uzmanlar ve firma yöneticilerinin tecrübelerinden faydalanılmanın yanı sıra görevlerin bizzat uygulama alanlarında gözlemlenmesi metodu da kullanılmıştır. Önerilen KP modelinin performansı PGÇP için bir çözüm önerisi sunan Pınarbaşı ve Alakaş (2020) çalışması ve EPGÇP için bir matematiksel model önerisi yapan Alakaş vd. (2020) çalışması sonuçları ile karşılaştırılmıştır. Yapılan karşılaştırmalı değerlendirmeler önerilen KP modelinin problemin çözümü için etkili ve umut vadedici bir yaklaşım olduğunu göstermiştir. Gelecek çalışma önerileri olarak dikkate alınan problemin görev sürelerini bir dağılıma uyduğunu kabul etmek, personellerin sağlık ve yeteneklerini de dikkate almak, görevlerin planlama ufkunu genişletmek gibi önerilerde bulunmak mümkündür. Modelin büyük veri setli problemlerin çözümünde etkili olabilmesi yeni KP arama stratejilerinin geliştirilmesi, KP ve sezgisel bütünleşik çözüm metotlarının geliştirilmesi de umut vadedici gelecek çalışma önerileri olarak verilebilir. Bunların yanı sıra ışık, termal etki, metabolik faktörler gibi farklı ergonomik ölçütlerin dikkate alındığı yeni problemler de dikkate değer gelecek bir çalışma olacaktır.

\section{Ek A. REBA Skor Tabloları}

Bu bölümde Bölüm 3'te REBA skoru hesaplama algoritmasında kullanılan skor tabloları verilmiștir. Bölüm 3'te bahsedilen ilgili skor Tablo A, Tablo B, Tablo C, Tablo D ve Tablo E'den uygun olanı seçilerek belirlenebilir.

Tablo A. Gövde, boyun ve bacak pozisyonları için skor tablosu

\begin{tabular}{|c|c|c|c|c|c|c|c|c|c|c|c|c|c|}
\hline \multirow[b]{3}{*}{ Skor A } & \multicolumn{13}{|c|}{ Boyun } \\
\hline & \multirow[b]{2}{*}{ Bacak } & \multicolumn{4}{|c|}{1} & \multicolumn{4}{|c|}{2} & \multicolumn{4}{|c|}{3} \\
\hline & & 1 & 2 & 3 & 4 & 1 & 2 & 3 & 4 & 1 & 2 & 3 & 4 \\
\hline \multirow[t]{5}{*}{ Gövde } & 1 & 1 & 2 & 3 & 4 & 1 & 2 & 3 & 5 & 3 & 3 & 5 & 6 \\
\hline & 2 & 2 & 3 & 4 & 5 & 3 & 4 & 5 & 6 & 4 & 5 & 6 & 7 \\
\hline & 3 & 2 & 4 & 5 & 6 & 4 & 5 & 6 & 7 & 5 & 6 & 7 & 8 \\
\hline & 4 & 3 & 5 & 6 & 7 & 5 & 6 & 7 & 8 & 6 & 7 & 8 & 9 \\
\hline & 5 & 4 & 6 & 7 & 8 & 6 & 7 & 8 & 9 & 7 & 8 & 9 & 9 \\
\hline
\end{tabular}


Tablo B. Üst kol, alt kol ve bilek pozisyonları için skor tablosu

\begin{tabular}{|c|c|c|c|c|c|c|c|}
\hline \multirow{3}{*}{ Skor B } & \multicolumn{9}{|c|}{ Alt kol } & \multicolumn{3}{|c|}{2} \\
\cline { 2 - 8 } & & \multicolumn{3}{|c|}{1} & 1 & \\
\cline { 2 - 8 } & Bilek & 1 & 2 & 3 & 1 & 2 & 3 \\
\hline \multirow{4}{*}{ Üst kol } & 1 & 1 & 2 & 2 & 1 & 2 & 3 \\
\cline { 2 - 8 } & 2 & 1 & 2 & 3 & 2 & 3 & 4 \\
\cline { 2 - 8 } & 3 & 3 & 4 & 5 & 4 & 5 & 5 \\
\cline { 2 - 8 } & 4 & 4 & 5 & 5 & 5 & 6 & 7 \\
\cline { 2 - 8 } & 5 & 6 & 7 & 8 & 7 & 8 & 8 \\
\cline { 2 - 8 } & 6 & 7 & 8 & 8 & 8 & 9 & 9 \\
\hline
\end{tabular}

Tablo C. Genel skor matrisi

\begin{tabular}{|c|c|c|c|c|c|c|c|c|c|c|c|c|}
\hline & \multicolumn{10}{|c|}{ Skor C } \\
\cline { 2 - 14 } $\begin{array}{c}\text { Skor A } \\
\text { (Tablo A } \\
\text { yük/kuvvet } \\
\text { skoru) }\end{array}$ & \multicolumn{10}{|c|}{} \\
\cline { 2 - 15 } & 1 & 2 & 3 & 4 & 5 & 6 & 7 & 8 & 9 & 10 & 11 & 12 \\
\hline 1 & 1 & 1 & 1 & 2 & 3 & 3 & 4 & 5 & 6 & 7 & 7 & 7 \\
\hline 2 & 1 & 2 & 2 & 3 & 4 & 4 & 5 & 6 & 6 & 7 & 7 & 8 \\
\hline 3 & 2 & 3 & 3 & 3 & 4 & 5 & 6 & 7 & 7 & 8 & 8 & 8 \\
\hline 4 & 3 & 4 & 4 & 4 & 5 & 6 & 7 & 8 & 8 & 9 & 9 & 9 \\
\hline 5 & 4 & 4 & 4 & 5 & 6 & 7 & 8 & 8 & 9 & 9 & 9 & 9 \\
\hline 6 & 6 & 6 & 6 & 7 & 8 & 8 & 9 & 9 & 10 & 10 & 10 & 10 \\
\hline 7 & 7 & 7 & 7 & 8 & 9 & 9 & 9 & 10 & 10 & 11 & 11 & 11 \\
\hline 8 & 8 & 8 & 8 & 9 & 10 & 10 & 10 & 10 & 10 & 11 & 11 & 11 \\
\hline 9 & 9 & 9 & 9 & 10 & 10 & 10 & 11 & 11 & 11 & 12 & 12 & 12 \\
\hline 10 & 10 & 10 & 10 & 11 & 11 & 11 & 11 & 12 & 12 & 12 & 12 & 12 \\
\hline 11 & 11 & 11 & 11 & 11 & 11 & 12 & 12 & 12 & 12 & 12 & 12 & 12 \\
\hline 12 & 12 & 12 & 12 & 12 & 12 & 12 & 12 & 12 & 12 & 12 & 12 & 12 \\
\hline & & & & & & & & & & & \\
\hline
\end{tabular}

Tablo D. Aktivite skoru

\begin{tabular}{|l|}
\hline+1, bir veya birden fazla vücut parçası bir dakikadan daha uzun süre statiktir. \\
\hline+1, Tekrarlanan küçük hareketler (dakikadan dörtten fazla hareket) \\
\hline $\begin{array}{l}\text { +1, Görev vücut duruşu veya dengesinde hızlı ve geniş aralıklı değişkenliğe } \\
\text { sahiptir. }\end{array}$ \\
\hline
\end{tabular}

Tablo E. REBA genel skoru

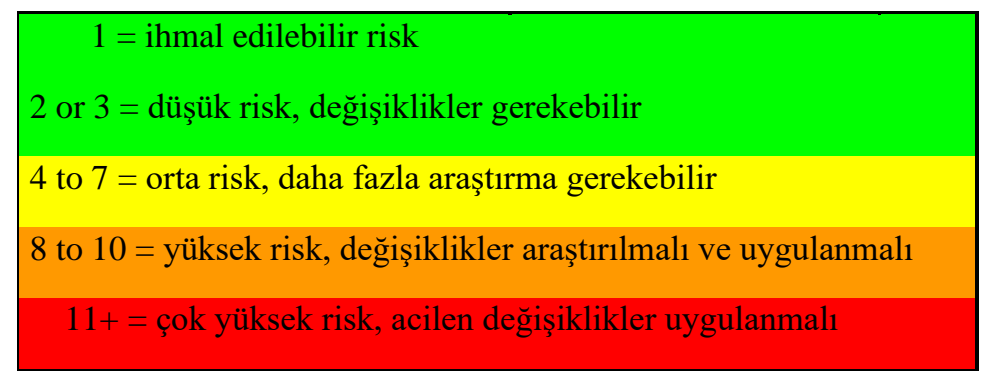




\section{Referanslar}

Adem, A., \& Dağdeviren, M. (2016). Ergonomik personel çizelgeleme konusu üzerinde bir literatür araştirmasi. Uluslararasi 16. Üretim Araştirmalari Sempozyumu, İstanbul Teknik Üniversitesi, 12-14 Ekim, 9-14, İstanbul, Türkiye.

Alakaş, H , Pınarbaşı, M , Sönmez, İ, \& Yüksel, A. (2020). Ergonomic personnel-task scheduling problem: A medium voltage insurance production application. Journal of Turkish Operations Management, 4(2), 433-448.

Anzanello, M.J., Fogliatto, F.S. \& Santos, L. (2014). Learning dependent job scheduling in mass customized scenarios considering ergonomic factors. Int. J. Production Economics, 154, 136-145.

Cuesta-Asensio, S., Diego-Mas, J.A., Canós-Darós, L., \& Andrés-Romano, C. (2012). A genetic algorithm for the design of job rotation schedules considering ergonomic and competence criteria. The International Journal of Advanced Manufacturing Technology, 60(912), 1161-1174.

Bedir, N., Eren, T., \& Dizdar, E.N. (2017). Ergonomik Personel Çizelgeleme ve Perakende Sektöründe Bir Uygulama. Journal of Engineering Sciences and Design, 5(3), 657 - 674.

Boenzi, F., Digiesi, S., Mossa, G., Mummolo, G., \& Romano, V.A. (2015). Modelling Workforce Aging in Job Rotation Problems. IFAC- PapersOnLine, 48(3), 604-609.

Carnahan, B., Redfern, M.S. \& Norman, B. (2000). Designing safe job rotation schedules using optimization and heuristic search, Ergonomics, 43(4), 543-560.

Charnes, A. \& Cooper, W.W. (1977). Goal programming and multiple objective optimizations: Part 1. European Journal Of Operational Research, 1(1), 39-54.

De Silva, A. (2001). Combining constraint programming and linear programming on an example of bus driver scheduling. Annals of Operations Research, 108(1-4), 277-291.

Eren T., Özder E.H., Alakaş H.M., \& Özcan E. (2019). Kısıt Programlama Yaklaşımıyla Güvenlik Personeli Çizelgeleme Probleminin Çözümü. Harran Üniversitesi Mühendislik Dergisi, 4(2), 16-25.

Gür, Ş., Eren, T., \& Alakaş, H.M. (2019). Surgical Operation Scheduling with Goal Programming and Constraint Programming: A Case Study. Mathematics, 7, 251.

Hignett, S. \& Mcatamney, L. (2000). Rapid entire body assessment (REBA). Applied ergonomics, 31(2), 201-205.

Kaçmaz, S., Alakaş, H., \& Eren, T. (2020). Ergonomic Staff Scheduling Problem With Goal Programming In Glass Industry. Journal of Turkish Operations Management, 4(1), 369-377.

Kostreva, M., McNeli, E. \& Clemens, E. (2002). Using a circadian rhythms model to evaluate shift schedules. Ergonomics, 45(11), 739-763.

Malladi, S. \& Min, K. J. (2004). Workforce scheduling with costs and ergonomic considerations. Paper presented at the IIE Annual Conference, Institute of Industrial Engineers, May 15-19, 2004, Hilton Americas, Houston, Texas.

Mossa, G., Boenzi, F., Digiesi, S., Mummolo, G., \& Romano, V.A. (2016). Productivity and ergonomic risk in human based production systems: A job-rotation scheduling model. Int. J. Production Economics, 171, 471-477.

Otto, A. \& Scholl, A. (2013). Reducing ergonomic risks by job rotation scheduling. OR Spectrum 35, 711-733.

Özcan, E., Alakaş, H.M., Yelek, A., \& Eren, T. (2020). Kısıt programlama ve hedef programlama entegrasyonu ile vardiya çizelgelemesi: Hidroelektrik santral uygulaması. Konya Mühendislik Bilimleri Dergisi, 8(4), 916-929.

Özder, E.H., Özcan, E., \& Eren, T. (2020). A systematic literature review for personnel scheduling problems. International Journal of Information Technology \& Decision Making, 19(06), 1695-1735. 
Pınarbaşı, M. (2021). New chance-constrained models for U-type stochastic assembly line balancing problem. Soft Computing, 25, 9559-9573.

Pınarbaş1, M., \& Alakaş, H.M. (2020). Personel Görev Çizelgeleme Problemi İçin Bir Excel Çözücü Modeli: Orta Gerilim Sigorta Üretimi Uygulaması. International Journal of Engineering Research and Development, 12(2), 729-744.

Pour, S.M., Drake, J.H., Ejlertsen, L.S., Rasmussen, K.M., \& Burke, E. (2018). Constraint Programming/Mixed Integer Programming framework for the preventive signaling maintenance crew scheduling problem. European Journal of Operational Research, 269(1), 341-352.

Rattanamanee, T. \& Nanthavanij, S. (2013). Multi-Workday Ergonomic Workforce Scheduling With Days Off. Proceedings of the 4th International Conference on Engineering, Project, and Production Management, 1(1), 1117-1125.

Rodriguez, J. (2007). A Constraint programming model for real-time train scheduling at junctions. Transportation Research Part B: Methodological, 41(2), 231-245.

Seçkiner, S.U. \& Kurt, M. (2005). Bütünleşik Tur-Rotasyon Çizelgeleme Yaklaşimi İle İşyükü Minimizasyonu. Gazi Üniversitesi Mühendislik-Mimarlık Fakültesi Dergisi, 20(2), 161-169.

Trilling, L., Guinet, A., \& Le Magny, D. (2006). Nurse scheduling using integer linear programming and constraint programming. IFAC Proceedings Volumes, 39(3), 671-676.

Wang, T.C. \& Liu, C.C. (2014). Optimal Work Shift Scheduling with Fatigue Minimization and Day Off Preferences. Mathematical Problems in Engineering, 1(1), 1-8.

Wongwien, T. \& Nanthavanij, S. (2012). Ergonomic workforce scheduling under complex worker limitation and task requirements: Mathematical model and approximation procedure. Songklanakarin Journal of Science \& Technology, 34(5), 541-549.

Wongwien, T. \& Nanthavanij, S. (2013). Ergonomic Workforce Scheduling With Productivity And Employee Satisfaction Consideration. Proceedings of the 4th International Conference on Engineering, Project, and Production Management, 1(1), 11081116.

Yaoyuenyong, S. \& Nanthavanij, S. (2006). Hybrid procedure to determine optimal workforce without noise hazard exposure. Computers \& Industrial Engineering, 51(4), 743-764. 